\title{
The Sand Fly Fauna (Diptera: Psychodidae: Phlebotominae) of a Focus of Cutaneous Leishmaniasis in Ilhéus, State of Bahia, Brazil
}

\author{
Alfredo CR Azevedo, Maurício L Vilela, Nataly A Souza, Claudia A Andrade- \\ Coelho, André F Barbosa, Antônio LS Firmo*, Elizabeth F Rangel
}

Laboratório de Vetores de Leishmaniose e Oncocercose, Departamento de Entomologia, Instituto Oswaldo Cruz, Av. Brasil 4365, 21045-900 Rio de Janeiro, RJ, Brasil *Fundação Nacional de Saúde, Ilhéus, BA, Brasil

The municipality of Ilhéus, State of Bahia, has a focus of cutaneous leishmaniasis where entomological studies were carried out to determine the sand fly species and their habits. Lutzomyia migonei, L. sallesi, L. tupynambai, L. schreiberi, L. intermedia, L. whitmani, L. yuilli yuilli, L. fischeri, L. pessoai, L. shannoni and L. misionensis were identified.

Lutzomyia whitmani was the predominant species. Specimens were collected indoors, at peridomestic sites, in the cocoa plantations and in other types of collections. Females fed readily on humans and were attracted to domestic animals. Our evidence suggests that L. whitmani is a probable vector.

Key words: sand fly fauna - cutaneous leishmaniasis - State of Bahia - Brazil

American Cutaneous Leishmaniasis (ACL), caused by Leishmania (V.) braziliensis, is one of the parasitic diseases of high incidence in some states of northeast Brazil. The municipality of Ilhéus, State of Bahia, is an endemic area of ACL. There are several cases of mucosal involvement (FNS - Fundação Nacional de Saúde 1991, personal comunication). We decided, in collaboration with FNS in 1990, to identify the local sand fly fauna and to study those aspects of the biology of the sand fly species as related to their role as vectors in some endemic areas in this region.

At present, no control measures have been applied in this region. Therefore, data obtained from these studies may be helpful in planning control programmes.

\section{MATERIALS AND METHODS}

Study area and meteorological data - The municipality of Ilhéus is located about $462 \mathrm{~km}$ from Salvador City (14.50' latitude South and $39^{\circ} 06^{\prime}$ longitude West). It has a wet, hot tropical climate and high annual rainfall (1,500-2,000 $\mathrm{mm})$. In the past, it was covered by "Mata Atlântica" forest, but now consists of plantations of cocoa-tree, the regions major economical agricultural activity.

We worked at two sites: Violeta and Cipó farms, where the average temperature ranged between $19^{\circ} \mathrm{C}$ and $29^{\circ} \mathrm{C}$, and relative humidity was $87 \%$.

Sand fly captures - These were carried out be-

Work supported by CNPq, Brazil grant no. 40.3371/ 90-2

Received 19 January 1995

Accepted 18 September 1995 tween 18:00 hr and 20:00 hr one week per month (December 1990, February, March, September and October 1991, March until August, and November 1992). Sand flies were captured in houses, on the inside and outside walls, using manual aspirators; at peridomestic sites (up to $10 \mathrm{~m}$ from houses) using manual aspirators on equines, and by CDC light traps (Sudia \& Chamberlain 1962, Gomes et al. 1985, Natal et al. 1991) in domestic animal shelters. In cocoa plantations, a Shannon trap (Sherlock \& Pessoa 1964) was used for collections up to $50 \mathrm{~m}$ and $100 \mathrm{~m}$ from houses, and a Falcão light trap (Falcão 1981, Aguiar et al. 1985) was used only to capture $100 \mathrm{~m}$ from houses.

The degree of anthropophily was determined by considering the number of females collected bitting man, in peridomestic sites and in cocoa plantations.

Identification of sand fly species - Sand flies were stored in $70 \%$ ethyl alcohol and later preserved on slides, using Berlese's medium, for taxonomic studies.

Search for natural infections of sand flies Some captured females were kept in cages, in plastic bags with high humidity, and dissected in physiological saline, within $24 \mathrm{hr}$. These were identified by their spermathecae during the dissections.

\section{RESULTS}

Sand fly fauna - During $242 \mathrm{hr}$ we collected a total of 8695 specimens belonging to the following Lutzomyia species, listed according to the classification by Young and Duncan (1994):

Group Migonei Theodor, 1965

L. migonei (França, 1920) 
L. sallesi (Galvão \& Coutinho, 1939)

L. tupynambai (Mangabeira, 1942)

Subgenus Micropygomyia Barretto, 1962

L. schreiberi Martins, Falcão \& Silva, 1975

Subgenus Nyssomyia Barretto, 1962

L. intermedia (Lutz \& Neiva, 1912)

L. whitmani (Antunes \& Coutinho, 1939)

L. yuilli yuilli Young \& Porter, 1972

Subgenus Pintomyia Costa Lima, 1932

L. fischeri (Pinto, 1926)

L. pessoai (Coutinho \& Barretto, 1940)

L. sp.

Subgenus Psathyromyia Barretto, 1962

L. shannoni (Dyar, 1929)

Subgenus Psychodopygus Mangabeira, 1941

L. sp.

Ungrouped species

L. misionensis (Castro, 1959)

The predominance of $L$. whitmani $\quad(97.7 \%)$ over the other collected species was very evident. Lutzomyia intermedia ( $1 \%$ ) followed in abundance and the other species appeared in much lower percentages (Table).

\section{TABLE}

Sand flies collected in Ilhéus, Bahia, Brazil. December 1990, February, March, September and October 1991, March-August and November 1992

\begin{tabular}{lcccr}
\hline Sand flies species & Females & Males & Total & $\%$ \\
\hline L. migonei & 8 & 11 & 19 & 0.2 \\
L. sallesi & 1 & - & 1 & 0.0 \\
L. tupynambai & 2 & - & 2 & 0.0 \\
L. schreiberi & 5 & 1 & 6 & 0.1 \\
L. intermedia & 52 & 39 & 91 & 1.0 \\
L. whitmani & 3099 & 5390 & 8489 & 97.7 \\
L. y. yuilli & 1 & - & 1 & 0.0 \\
L. fischeri & 34 & 14 & 48 & 0.6 \\
L. pessoai & 7 & 1 & 8 & 0.1 \\
L. (Pi) sp. & 6 & - & 6 & 0.1 \\
L. shannomi & 1 & - & 1 & 0.0 \\
L. (Ps) sp. & 1 & 2 & 3 & 0.0 \\
L. minionensis & 20 & - & 20 & 0.2 \\
\hline Total & 3237 & 5458 & 8695 & 100.0
\end{tabular}

\section{L.: Lutzomyia}

Frequency of species caught with differents type and site of captures - In $108 \mathrm{hr}$ we collected 6327 specimens from inside and outside houses: L. whitmani $(97.8 \%)$ was the most common captured species. We also collected L. migonei, L. sallesi, L. tupynambai, L. schreiberi, L. intermedia, L. fischeri, L. pessoai, L. (Pi) sp, $L$. shannoni and L. misonensis. ( Fig.1 ).

From light traps in domestic animals shelters, we collected 274 specimens. In a chicken-house

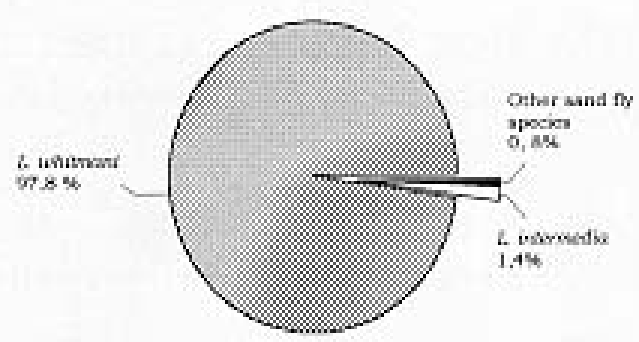

A

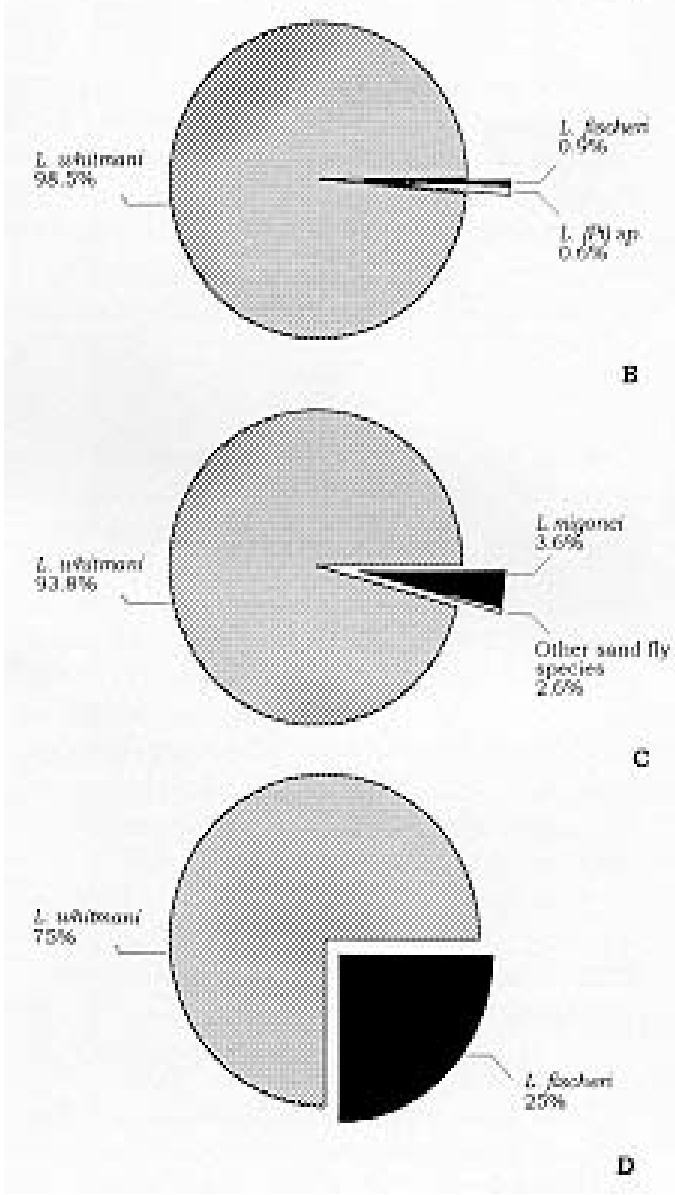

Fig. 1: frequency of Lutzomyia whitmani on A: inside houses, B: animal bait (equine) and $\mathrm{C}, \mathrm{D}$ : in domestic animal shelters $(\mathrm{C}=$ chicken house, $\mathrm{D}=$ cowshed).

most sand flies captured in $22 \mathrm{hr}$ were $L$. whitmani (93.8\%). Lutzomyia migonei, L. tupynambai, $L$. intermedia, L. fischeri, L. pessoai and $L$. (Pi) sp. were also found. In the cowshed, only two species were caught (56 specimens in $10 \mathrm{hr}$ ): L. whitmani $(75 \%)$ and L. fischeri $(25 \%)$. The number of sand flies attracted to equines, during $16 \mathrm{hr}$, was 318 and again most were L.whitmani $(98.5 \%)$, followed by L. fischeri (0.9\%) and L. (Pi) sp. (Fig.1).

In cocoa plantations (during $86 \mathrm{hr}$ ) we collected 1720 specimens. Near houses (994 speci- 
mens), L. migonei, L. y. yuilli and L. misionensis were found, with $L$. whitmani predominating (97.9\%). As far as $100 \mathrm{~m}$ from houses (694 specimens), only two species were collected - $L$. whitmani (99.9\%) and L. misionensis (0.1\%). Further away from houses when a Falcão light trap was used (32 specimens), L. whitmani (75.8\%), L. pessoai (9.1\%), L. fischeri and L. misionensis were collected (Fig. 2).

The specimens identified as Lutzomyia spp. are related to subgenera Psychodopygus (possibly L. ayrozai) and Pintomyia sp. that may be an undescribed species.

Search for natural infections - We dissected 225 specimens, but no infections were detected.

Although we have not yet identified the Leishmania isolated from patients, the clinical and parasitological features indicate that the disease in Ilhéus is caused by Le. (V.) braziliensis.

\section{DISCUSSION}

Our survey in Ilhéus indicated the presence of 13 species of sand flies, most of which were captured in houses and in peridomiciliary surroundings. At both areas L. whitmani was predominant, and was present in each type of collection. This finding supports previous studies, in the States of São Paulo (Barretto 1943, Forattini 1960, Taniguchi et al. 1991), Minas Gerais (Mayrink et al. 1979), Bahia (Barretto et al. 1982, Vexenat et al. 1986) and Ceará (Azevedo \& Rangel 1991), where L. whitmani was recorded in domestic habitats.

In spite of its high degree of anthropophily, $L$. whitmani is also attracted to domestic animals, suggesting its adaptation to the domestic habitat.

This sand fly species is considered a vector of Le. (V.) braziliensis in other endemic areas of northeast and southeast Brazil, where it enters dwellings places and sites near houses (Pessoa \& Coutinho 1941, Mayrink et al. 1979, Azevedo et al. 1990, Queiroz et al. 1991). In Três Braços, State of Bahia, the high percentage of $L$. whitmani inside houses and in peridomestic sites, associated with the presence of infected specimens with Le.(V.) braziliensis in peridomi-ciliary areas, suggests a domestic or peridomestic transmission cycle of ACL (Hoch et al. 1986, Ryan et al. 1990).

Because the primary forest in this area has been replaced by several types of agriculture, mostly cocoa tree cultivation, we suggest that domestic and peridomestic transmission is occuring. Although no natural infection of Leishmania was found in L. whitmani, our studies suggest that this sand fly species is the vector because it feeds readily on humans and is the predominant
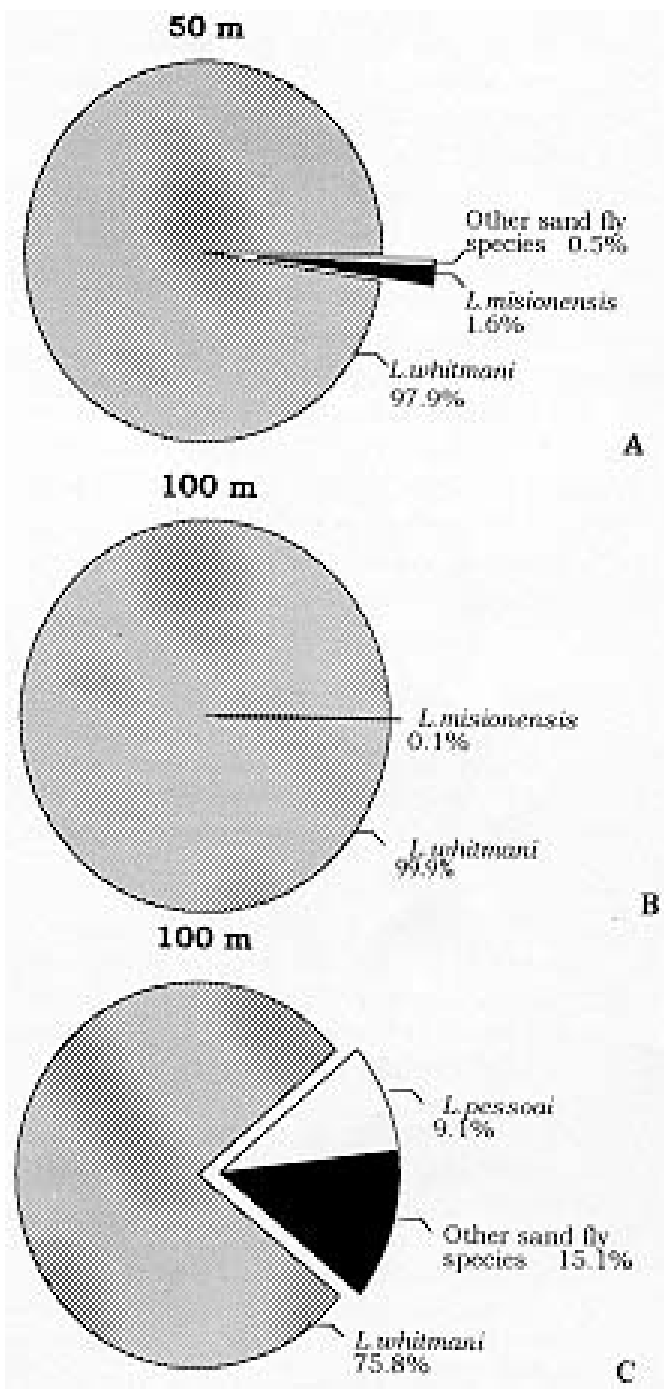

Fig. 2: frequency of Lutzomyia whitmani in plantations of cocoa. A, B: using Shannon trap, and C: using light trap.

species in domestic and peridomestic sites, where a peridomestic transmission cycle involving a domestic reservoir may be occurring. On the other hand, we cannot dismiss the likelihood that transmission may also occur in cocoa plantations, indicating, that it is also an occupational disease.

Recently, Rangel (1993) studied L. whitmani by comparing populations from States of Pará, Ceará and Bahia. Sand flies from these areas are morphologically very similar but have distinct behaviorial characteristics. When the author used morphometric characters, genomic DNA fragments as diagnostic probes and phylogenetic analysis, this survey showed strong evidence that there are at least two distinctive forms of this 
sand fly species, that are geographically isolated: one occurrring in State of Pará (north Brazil) and the other in northeast Brazil (States of Ceará and Bahia, including Ilheús, this type locality). This suggests the possibility that these two forms are involved in the transmission of ACL in two different environments.

We found two other sand fly species in Ilhéus, L. intermedia and L. migonei, which are involved in the transmission of ACL due to Le. (V.) braziliensis in other states from northeast and southeast Brazil (Araújo Filho 1979, Rangel et al. 1984, 1986, 1990, Azevedo et al. 1990). In the present study area, these species are uncommon and we believe that they are not transmiting the disease to man.

\section{ACKNOWLEDGEMENTS}

To Jorair Souza e Silva, Eliésio Bezerra da Silva, Augustinho Freire Demétrio, Moacir Vieira de Oliveira, Paulo Raimundo Barbosa and Antônio Carlos Conceição Menezes,technicians from Fundação Nacional de Saúde, Brazil for support in field works.

\section{REFERENCES}

Aguiar GM, Vilela ML, Schuback PA, Soucasaux T, Azevedo ACR 1985. Aspectos da ecologia dos flebótomos do Parque Nacional da Serra dos Órgãos, Rio de Janeiro. IV Frequência mensal em armadilhas luminosas (Diptera, Psychodidae, Phlebotominae). Mem Inst Oswaldo Cruz 80: 465-482.

Araujo Filho NA 1979. Epidemiologia da leishmaniose tegumentar na Ilha Grande Thesis, Univesidade Federal do Rio de Janeiro, 144p.

Azevedo ACR, Rangel EF 1991. A study of sand fly species (Diptera, Psychodidae, Phlebotominae) in a focus of cutaneous leishmaniasis in the municipality of Baturité, Ceará, Brazil. Mem Inst Oswaldo Cruz 86: 405-410.

Azevedo ACR, Rangel EF, Costa ME, David J, Vasconcelos AW, Lopes UG 1990. Natural infection of Lutzomyia (Nyssomyia) whitmani (Antunes \& Coutinho, 1939) by the Leishmania of the braziliensis complex in Baturité, Ceará, Northeast Brazil. Mem Inst Oswaldo Cruz 85: 251.

Barreto AC, Vexenat JA, Cuba-Cuba CA, Marsden PD 1982. Fauna flebotomínica de uma região endêmica de leishmaniose cutâneo-mucosa, no Estado da Bahia, Brasil. IX Reunião Anual sobre Pesquisa Básica em Doença de Chagas, p.147.

Barretto MP 1943. Observações sobre a biologia em condições naturais dos flebotómos do Estado de SãoPaulo(Diptera:Psychodidae). Thesis, Faculdade de Medicina, Universidade de São Paulo, 162 pp.

Falcão 1981. Um novo modelo de armadilha luminosa de sucção para pequenos insetos. Mem Inst Oswaldo Cruz 76: 303-305.

Forattini OP 1960. Novas observações sobre a biologia de flebótomos em condições naturais (Diptera: Psychodidae). Arquiv Fac Hig Saúde Públ 25: 209-
215.

Gomes AC, Rabello EX, Natal D 1985. Uma nova câmara coletora para armadilha CDC miniatura. Rev Saúde Públ São Paulo 19: 190-191.

Hoch A, Ryan L, Vexenat JA, Rosa AC, Barreto AC 1986. Isolation of Leishmania braziliensis braziliensis and other trypanosomatids from Phlebotomine in a mucocutaneous leishmaniasis endemic area, Bahia, Brazil. Mem Inst Oswaldo Cruz 81 (Suppl.): 62.

Mayrink W, Williams P, Coelho MV, Dias M, Martins AV 1979. Epidemiology of dermal leishmaniasis in the Rio Doce Valley, State of Minas Gerais, Brazil. Ann Trop Med Parasitol 73: 123-137.

Natal D, Marucci D, Reis IM, Galati EAB 1991. Modificação da armadilha CDC com testes para coletas de flebotomíneos (Diptera). Rev Brasil Ent 35: 697-700.

Pessoa SB, Coutinho JO 1941. Infecção natural e experimental dos flebótomos pela Leishmania braziliensis no Estado de São Paulo. Hospital 20: 25-35.

Queiroz RG, Vasconcelos I, Vasconcelos AW, Souza ARN, David J 1991. New world phlebotomine sand flies as hosts of Leishmania (V.) braziliensis in an endemic area of cutaneous leishmaniasis in Ceará State, Northeast Brazil. First International Symposium on Phlebotomine Sandlies, Rome, p. 87

Rangel EF 1993. Estudo comparativo de três populações de Lutzomyia (Nyssomyia) whitmani (Antunes \& Coutinho, 1939) (Diptera, Psychodidae, Phlebotominae). Thesis, Instituto de Ciências Biológicas, Universidade de São Paulo, 90 pp.

Rangel EF, Azevedo ACR, Andrade CA, Souza NA, Wermelinger ED 1990. Studies on sand fly fauna (Diptera: Psychodidae) in a focus of cutaneous leishmaniasis in Mesquita, Rio de Janeiro State, Brazil. Mem Inst OswaldoCruz 85: 39-45.

Rangel EF, Souza NA, Wermelinger ED, Azevedo ACR, Barbosa AF, Andrade CA 1986. Flebótomos de Vargem Grande, foco de leishmaniose tegumen-tar no Estado do Rio de Janeiro. Mem Inst Oswaldo Cruz 81: 347-349.

Rangel EF, Souza NA, Wermelinger ED, Barbosa AF 1984. Infecção natural de Lutzomyia intermedia (Lutz \& Neiva, 1912) em área endêmica de leishmaniose tegumentar no Estado do Rio de Janeiro. Mem Inst Oswaldo Cruz 79: 395-396.

Ryan L, Vexenat JA, Marsden PD, Lainson R, Shaw JJ 1990. The importance of rapid diagnosis of new cases of cutaneous leishmaniasis in pin-pointing the sand fly vector. Trans $R$ Soc Trop Med Hyg 84: 786.

Scherlock IA, Pessoa SB 1964. Métodos práticos para a captura de flebótomos. Rev Brasil Biol 24: 331-340.

Sudia WD, Chamberlain RW 1962. Battery-operated light trap, an improved model. Mosquito News 22: $126-129$.

Taniguchi HH, Tolezano JE, Correa FMA, Moraes RHP, Veiga RM, Marassa AM 1991. Epidemiologia 
da leishmaniose americana no Estado de São Paulo, Brasil. 1. Composição da fauna flebotomínica no Município de São Roque, Região de Sorocaba . Rev Inst Adolfo Lutz 51: 23-30.

Tolezano JE, Novelli MA,Taniguchi HH 1992. Leishmaniose tegumentar no Estado de São Paulo. VI. Avaliação do comportamento antropofílico de flebótomos em áreas endêmicas. Mem Inst Oswaldo Cruz 87 (Suppl.): 219.

Vexenat JA, Barreto AC, Cuba-Cuba CA, Marsden
PD 1986. Características epidemiológicas da leishmaniose tegumentar americana em uma região endêmica do Estado da Bahia. III. Fauna flebotomínica. Mem Inst Oswaldo Cruz 81: 293302.

Young DG, Duncan MA 1994. Guide to the identification and geographic distribution of Lutzomyia sand flies in Mexico, the West Indies, Central and South America (Diptera: Psychodidae). Mem Amer Ent Inst 54: 1-881. 
